\title{
Frequency, Virulence, and Metalaxyl Sensitivity of Pythium spp. Isolated from Apple Roots Under Conventional and Organic Production Systems
}

\author{
Mark Mazzola, USDA-ARS, Tree Fruit Research Laboratory, Wenatchee, WA, 98801; Preston K. Andrews and \\ John P. Reganold, Department of Horticulture \& Landscape Architecture, Washington State University, Pullman \\ 99164; and C. André Lévesque, Eastern Cereal and Oilseed Research Centre, Agriculture \& Agri-Food Canada, \\ Ottawa, ON
}

\begin{abstract}
Mazzola, M., Andrews, P. K., Reganold, J. P., and Lévesque, C. A. 2002. Frequency, virulence, and metalaxyl sensitivity of Pythium spp. isolated from apple roots under conventional and organic production systems. Plant Dis. 86:669-675.

Studies were conducted to characterize the community of Pythium spp. associated with apple in Washington state. Seventeen different species were identified among the isolates of Pythium recovered from apple roots at six orchard sites. Commonly isolated species included $P$. intermedium, $P$. irregulare, $P$. heterothallicum, P. sylvaticum, and Pythium MM1 (aff. macrosporum), a previously undescribed species. The population of Pythium spp. at any given site typically was dominated by a single pathogenic species. Species composition of Pythium populations in adjacent conventional and organic blocks in two orchards did not differ; however, the relative recovery of Pythium spp. from apple roots was consistently lower in the organically managed systems. In greenhouse studies, the associations formed between apple seedlings and Pythium spp. ranged from pathogenic to growth-promoting. Precolonization of apple seedling roots with any one of three nonpathogenic isolates tested-isolate 584 of Pythium MM1, isolate 1-12 of Pythium MM3 (aff. oedochilum), and isolate 1-19 of Pythium MM5 (aff. vexans) -was found to provide biological control of root rot caused by P. sylvaticum and P. ultimum. Metalaxyl sensitivity varied among species of Pythium, with several nonpathogenic species exhibiting the highest levels of insensitivity to this fungicide.
\end{abstract}

Additional keywords: biological control, rhizosphere

Members of the genus Pythium are common inhabitants of agricultural soils and form diverse associations with a wide range of plant species. The genus Pythium encompasses no less than 100 different species (7), with many crop plants being susceptible to multiple species (32). Pythium spp. have been reported to reduce growth of apple (Malus domestica Borkh.) seedlings $(3,21)$ and are cited in numerous geographic regions as elements of pathogen complexes that incite apple replant disease $(8,18,28)$.

Although Pythium spp. can cause extensive root rot of apple, little is known as to which species play a significant role as

Corresponding author: M. Mazzola E-mail: mazzola@tfrl.ars.usda.gov

This work was supported, in part, by the Cooperative State Research, Education, and Extension Service, United States Department of Agriculture, under agreement no. 98-34103-6414, and the Washington Tree Fruit Research Commission.

Accepted for publication 12 February 2002.

Publication no. D-2002-0409-01R

This article is in the public domain and not copyrightable. It may be freely reprinted with customary crediting of the source. The American Phytopathological Society, 2002. pathogens of apple. Pythium irregulare $(3,11)$ and $P$. sylvaticum $(18,21,28)$ were shown to be highly virulent toward apple; however, there is a lack of information concerning the frequency and distribution of individual species in apple orchards. Likewise, associations between Pythium spp. and host plants are not limited to pathogenic interactions and certain species are known to have growth-promotion effects (6) or possess ability as agents for the biological control of soilborne diseases (14,16,22-24). Knowledge of the breadth of interactions and the species associated with apple may provide opportunities for the management and control of pathogenic Pythium spp.

Management practices have a significant impact on quantitative and qualitative attributes of soil microbial communities in agricultural ecosystems (4). Microbial biomass and activity often are higher in soils managed using organic practices than in the same soils cultivated using conventional methods (13). General soil suppressiveness often is correlated with higher levels of microbial activity. In Washington, a significant recent expansion in the acreage devoted to organic tree fruit production has been carried out, in part, due to the continued decline in economic returns for apples produced under conventional sys- tems. The impacts of this trend on soilborne pathogens in general, and Pythium spp. in particular, has not been of major concern but, in the long term, could pose significant benefits or liabilities should orchard renovation become necessary.

Practices implemented in the orchard could induce unintended long-term impacts on soil biology due to the perennial nature of orchard systems. Crown and root rot of apple caused by Phytophthora cactorum and some species of Pythium is a disease problem of common occurrence in all apple-growing regions of the world in both orchard and nursery settings $(10,12)$. Inoculum sources in the orchard environment are numerous and may include soil, rootstocks $(10,29)$, and irrigation water $(9,20)$. The fungicide metalaxyl commonly is applied once or more annually to control this disease. Such a practice has potential implications for managing root rot of apple caused by Pythium spp. and replant disease in geographic regions where this pathogen is an element of the causal pathogen complex. Although Phytophthora cactorum typically is the target of such treatments, reports of metalaxyl resistance among populations of this pathogen from apple orchard soils (30) may indicate the presence of metalaxyl resistance among populations of Pythium spp. from these environments.

The objectives of this study were to describe the composition of Pythium spp. populations associated with apple, determine the relative virulence of species of Pythium toward apple, characterize the impact of management system (conventional versus organic) on Pythium spp. populations, and determine the relative sensitivity of these fungi to the fungicide metalaxyl.

\section{MATERIALS AND METHODS}

Orchard study sites. Soil and root samples were obtained from five apple orchards in Washington; CV orchard (Columbia View Experimental Orchard), Orondo; DO orchard, Zillah; DTF orchard, Orondo, GC orchard, Manson; and WVC orchard (Wenatchee Valley College Sunnyslope Demonstration Orchard), Wenatchee. Plantings consisted of 'Gala' on M.26 rootstock at the CV and DTF orchards, 'Golden Delicious' on M.26 rootstock at the GC and DO orchards, and 
'Fuji' on M.9 rootstock at the WVC orchard. Trees were 2, 5, 7, 11, and 10 years old at the 1998 sampling in the CV, DO, DTF, GC, and WVC orchards, respectively. The DTF orchard contained adjoining conventional and organic production blocks, and the DO orchard consisted of four 0.14-ha replicate plots for conventional, organic, and integrated soil management systems arranged in a randomized complete block design (27). All other orchards were managed using conventional practices. There was no history of metalaxyl use at the study orchards, with the exception of the GC orchard, where the fungicide was applied as a soil drench in the spring of 1994 and 1995.

Sample collection. Root samples were collected from all sites during May and October 1998. At the CV, GC, and WVC orchards, samples were collected from six randomly selected trees at each site, with roots obtained at a depth of 5 to $15 \mathrm{~cm}$. Samples were collected from separate blocks at the DO and DTF orchards that were managed using organic or conventional management practices. At the DTF orchard, samples were collected from six trees in each system, and a total of eight trees were sampled from each soil management system at the DO orchard, representing two trees from each of four blocks. Root samples were collected from the DO orchard only in May of 1999. In addition to isolates obtained from these root samples, isolates from the DR orchard, Moxee, WA, previously obtained as part of a prior study (18), included $P$. ultimum and two newly described strains, designated Pythium MM3 and Pythium MM4. These isolates were evaluated in plant bioassays as described below.

Determination of soil populations and isolation of Pythium spp. from apple roots. Populations of Pythium spp. were determined by placing $5 \mathrm{~g}$ of soil in $25 \mathrm{ml}$ of sterile water, mixing on a titer plate shaker (Lab-Line Instruments, Inc., Melrose Park, IL) at highest speed for $10 \mathrm{~min}$, and vortexing for $60 \mathrm{~s}$ prior to plating serial dilutions of the resulting soil suspension on a medium semiselective for $P y$ thium spp. (PSSM; 19). Two 5-g subsamples were analyzed per soil sample with two replicate plates per dilution. Plates were incubated at room temperature (20 to $22^{\circ} \mathrm{C}$ ) and were examined at 24-h intervals for 4 days. Resulting colonies were counted and populations expressed as CFU.

Apple root systems were rinsed under tap water to remove adhering soil. For each root system, 20 current-year root segments (0.5 to $1.0 \mathrm{~cm}$ in length) and 20 segments from 1-year-old roots were plated onto PSSM. Hyphal growth from root segments was examined after 24 and $48 \mathrm{~h}$ incubation at room temperature $\left(20\right.$ to $\left.22^{\circ} \mathrm{C}\right)$ using a light microscope $(\times 100)$. Mycelia, sporangia, and oospores characteristic of Pythium spp. were transferred to water agar amended with ampicillin (100 $\left.\mu \mathrm{g} \mathrm{ml}^{-1}\right)$, and individual isolates were subsequently stored on one-fifth-strength potato dextrose agar (PDA; Difco Laboratories, Detroit).

Mycelium growth and DNA extraction. DNA was extracted from 7-day-old cultures grown in 14-ml polypropylene round-bottom tubes (Becton Dickinson Labware, Franklin Lakes, NJ) with $10 \mathrm{ml}$ of potato dextrose broth. Cultures were shaken at $200 \mathrm{rpm}$ on a rotary shaker. Approximately $200 \mathrm{mg}$ of mycelium was centrifuged in $1.5-\mathrm{ml}$ tubes for $2 \mathrm{~min}$ at $10,000 \times g$ and excess broth was removed. Then, $1 \mathrm{ml}$ of $1 \mathrm{M} \mathrm{NaCl}$ was added to the pellet, which was vortexed and processed as before to remove excess solution. DNA was extracted using a kit (Bio 101/Savant Fast DNA Kit H; Vista, CA), with the manufacturer's protocol \#6540-999-6J02 and the CLS-Y buffer, using the Fastprep instrument at power 5 for $20 \mathrm{~s}$.

DNA amplification. Universal eukaryotic primers UN-UP18S42 (5'CGTAACAAGGTTTCCGTAGGTGAAC$\left.3^{\prime}\right)$ with UN-LO28S576B (5'-CTCCTTGGTCCGTGTTTCAAGACG-3') were used to prepare the sequencing template by amplifying the internal transcribed spacer (ITS) regions, the $5.8 \mathrm{~S}$ gene of nuclear ribosomal DNA, and part of the large ribosomal subunit (1). DNA was amplified by polymerase chain reaction (PCR) in volumes of $50 \mu$ with 2 units of AmpliTaq polymerase (Perkin-Elmer Corp., Norwalk, $\mathrm{CT}$ ), each primer at $0.8 \mu \mathrm{M}, 1 \times$ manufacturer's buffer with $1.5 \mu \mathrm{M} \mathrm{MgCl}$, and each deoxynucleoside triphosphate at a concentration of $200 \mu \mathrm{M}$. Samples were placed in a DNA GENE AMP 2400 (Perkin-Elmer Corp.) thermal cycler at $95^{\circ} \mathrm{C}$ for $3 \mathrm{~min}$ for DNA denaturation, after which 31 cycles were performed as follows: $45 \mathrm{~s}$ at $95^{\circ} \mathrm{C}$, $30 \mathrm{~s}$ at $68^{\circ} \mathrm{C}$, and $1 \mathrm{~min}$ at $72^{\circ} \mathrm{C}$, with a final 10 -min extension at $72^{\circ} \mathrm{C}$. PCR product was purified using a Qiaquick kit (Qiagen, Chatsworth, CA) and quantified by visual comparison to a low DNA mass ladder (Cat No. 10068-013, Lot No. kDV 720; Gibco BRL, Gaithersburg, MD) following electrophoresis on a $1.75 \%$ agarose gel stained with ethidium bromide $(0.25$ $\mu \mathrm{g} / \mathrm{ml})$.

DNA sequencing. Purified template DNA (30 to $50 \mathrm{ng}$ ) was sequenced according to Perkin-Elmer protocol P/N 4303237 Rev. C (Big Dye Terminator Ready Reaction Kit) with the exception that the sequencing mix was diluted $1: 3$ with sequencing buffer (200 mM TrisHCl, $\mathrm{pH} 9.0$; $5 \mathrm{mM} \mathrm{MgCl}_{2}$ ) before use. The ITS 1 region was amplified using a universal eukaryote forward primer (UN-UP18S42) and a reverse primer (OOM-LO5.8S47B = 3'-CGCATTACGTATCGCAGTTCGCAG$\left.5^{\prime}\right)$ only when the forward primer gave ambiguous results. The ITS 1 and partial $5.8 \mathrm{~S}$ gene were subsequently sequenced as follows: reactions were placed in a DNA
GENEAMP 2400 thermal cycler for 25 cycles of $15 \mathrm{~s}$ at $95^{\circ} \mathrm{C}$ and $4.5 \mathrm{~min}$ at $60^{\circ} \mathrm{C}$. Extension products were purified by ethanol precipitation (ABI Prism Dye Terminator Cycle Sequencing Ready Reaction Kit, August 1995 protocol; Perkin-Elmer Corp.) and resuspended in template suppression reagent before being transferred into an ABI Prism Genetic Analyzer (model 310; Perkin-Elmer Corp.) for electrophoresis and analysis.

Sequences were edited using Sequence Navigator (ver. 1.01; Applied Biosystems, Perkin-Elmer Corp.). Genetics Computer Group (GCG) Wisconsin Package Version 9.0 software was used to perform final alignments for comparison with a database that contained all the (neo)type strains of Pythium spp. (C. A. Lévesque, unpublished data).

Inoculum production. Inoculum used in these studies consisted of amended soil (15) or Pythium sp.-colonized substrate. For amended soil inoculum, 1,500 g of soil was pasteurized at $95^{\circ} \mathrm{C}$ for $90 \mathrm{~min}$ and allowed to cool for $24 \mathrm{~h}$ prior to adding 15 $\mathrm{g}$ (dry weight) of chopped Romaine lettuce. The soil was pasteurized for an additional 90 min and again allowed to cool for $24 \mathrm{~h}$ prior to infesting the soil with an actively growing culture of a single Pythium sp. isolate. Infested soil was incubated at room temperature for 8 weeks, and subsequently allowed to air dry for 5 days. Pathogen density in the amended soil was determined by adding $5 \mathrm{~g}$ of soil to $25 \mathrm{ml}$ of sterile water and plating serial dilutions of the resulting soil suspension on PSSM agar as described above. Inoculum was adjusted to 400 propagules per gram (ppg) soil for each isolate by diluting with steam pasteurized soil prior to planting.

Alternatively, an oat bran-corn meal based inoculum was employed in plant assays. Growth substrate was prepared by placing $45 \mathrm{~g}$ of oat bran, $75 \mathrm{~g}$ of corn meal, and $90 \mathrm{ml}$ of sterile water in a 1-liter flask, and autoclaving for $90 \mathrm{~min}$ on two successive days. Five plugs (1.5-cm diameter) containing agar and mycelium were cut from a culture of each Pythium sp. growing on one-fifth-strength PDA and added to each flask. Cultures were incubated at room temperature $\left(20\right.$ to $22^{\circ} \mathrm{C}$ ) for 5 weeks, and the resulting inoculum was dried in a laminar flow hood for $48 \mathrm{~h}$.

Plant assays. Studies were conducted to determine the impact of various species of Pythium initially recovered from orchard soil or apple roots on growth of apple. Soil used in these assays was collected from noncultivated land adjacent to the Washington State University Tree Fruit Research and Extension Center in Wenatchee, WA. Soil was pasteurized $\left(95^{\circ} \mathrm{C}\right)$ for 90 min on two consecutive days prior to addition of Pythium spp. The experiment was conducted twice, using two different inoculation methods. Soil was amended with oat bran-corn meal inoculum at a concentra- 
tion of $0.2 \%(w t / w t)$ or adjusted to a $P y$ thium sp. propagule density of $400 \mathrm{ppg}$ using infested soil produced as described above.

'Gala' apple seedlings were produced in sterile potting medium as previously reported (18). Soil was dispensed into plastic pots (3.8 liters, 16-cm-diameter) with a total of three pots per isolate of Pythium spp., and five 8-week-old Gala seedlings were planted into each pot. All experiments included a noninfested soil treatment as the control. Plants were grown in the greenhouse at $24 \pm 4^{\circ} \mathrm{C}$ with supplemental lighting to maintain a $16-\mathrm{h}$ photoperiod. Plants were harvested after 8 or 12 weeks, roots were washed under tap water, and root weight, shoot weight, and shoot length were determined. Colonization of seedling roots by the respective isolates of Pythium spp. was determined by plating 10 arbitrarily selected root segments $(0.5$ to $1.0 \mathrm{~cm}$ in length) from each seedling onto PSSM. Root segments were examined microscopically after 48 and $72 \mathrm{~h}$ of incubation.

Studies were conducted to determine the ability of nonpathogenic Pythium spp. to control pathogenic species. Nonpathogenic isolates consisted of isolate 584 of Pythium MM1, isolate 1-12 of Pythium MM3, and isolate 1-19 of Pythium MM5; pathogens were $P$. sylvaticum 566 and $P$. ultimum 664. Four-week-old Gala seedlings were grown in sterile potting mix amended with oat

Table 1. Identity and number of Pythium spp. isolates recovered from roots of apple collected at six orchards in Washington state ${ }^{\mathrm{y}}$

\begin{tabular}{|c|c|c|c|c|c|}
\hline \multirow[b]{2}{*}{ Species } & \multicolumn{5}{|c|}{ Orchard $^{\mathbf{z}}$} \\
\hline & $\mathrm{CV}$ & DO & DTF & GC & WVC \\
\hline P. aphanidermatum & 1 & $\ldots$ & $\ldots$ & $\ldots$ & $\ldots$ \\
\hline P. debaryanum & $\ldots$ & $\ldots$ & 5 & $\ldots$ & $\ldots$ \\
\hline P. dissotocum & $\ldots$ & 1 & $\ldots$ & $\ldots$ & 5 \\
\hline P. flevoense & $\ldots$ & $\ldots$ & $\ldots$ & $\ldots$ & 1 \\
\hline P. heterothallicum & 33 & 16 & 2 & 1 & $\ldots$ \\
\hline P. intermedium & 7 & 127 & $\ldots$ & $\ldots$ & 1 \\
\hline P. irregulare & $\ldots$ & 2 & 8 & 1 & $\ldots$ \\
\hline P. iwayamae & 1 & $\ldots$ & $\ldots$ & 2 & $\ldots$ \\
\hline Pythium MM2 (aff. iwayamae) & $\ldots$ & 2 & $\ldots$ & $\ldots$ & 1 \\
\hline P. macrosporum & $\ldots$ & 1 & $\ldots$ & $\ldots$ & $\ldots$ \\
\hline Pythium MM1 (aff. macrosporum) & 1 & 13 & $\ldots$ & 3 & $\ldots$ \\
\hline Pythium MM3 (aff. oedochilum) & $\ldots$ & $\ldots$ & $\ldots$ & $\ldots$ & $\ldots$ \\
\hline Pythium MM4 (aff. rostratum) & $\ldots$ & 1 & $\ldots$ & 2 & 1 \\
\hline P. sylvaticum & $\ldots$ & 21 & 1 & 3 & 34 \\
\hline P. torulosum & $\ldots$ & 1 & $\ldots$ & $\ldots$ & $\ldots$ \\
\hline P. ultimum & $\ldots$ & $\ldots$ & 2 & $\ldots$ & $\ldots$ \\
\hline Pythium MM5 (aff. vexans) & $\ldots$ & $\ldots$ & $\ldots$ & $\ldots$ & 7 \\
\hline
\end{tabular}

y Values are the total number of isolates recovered from root samples in 1998, and include samples collected in May 1999 from DO orchard.

${ }^{\text {z }}$ CV orchard, Orondo; DO orchard, Zillah; DR orchard, Moxee; DTF orchard, Orondo, GC orchard, Manson; and WVC orchard, Wenatchee.

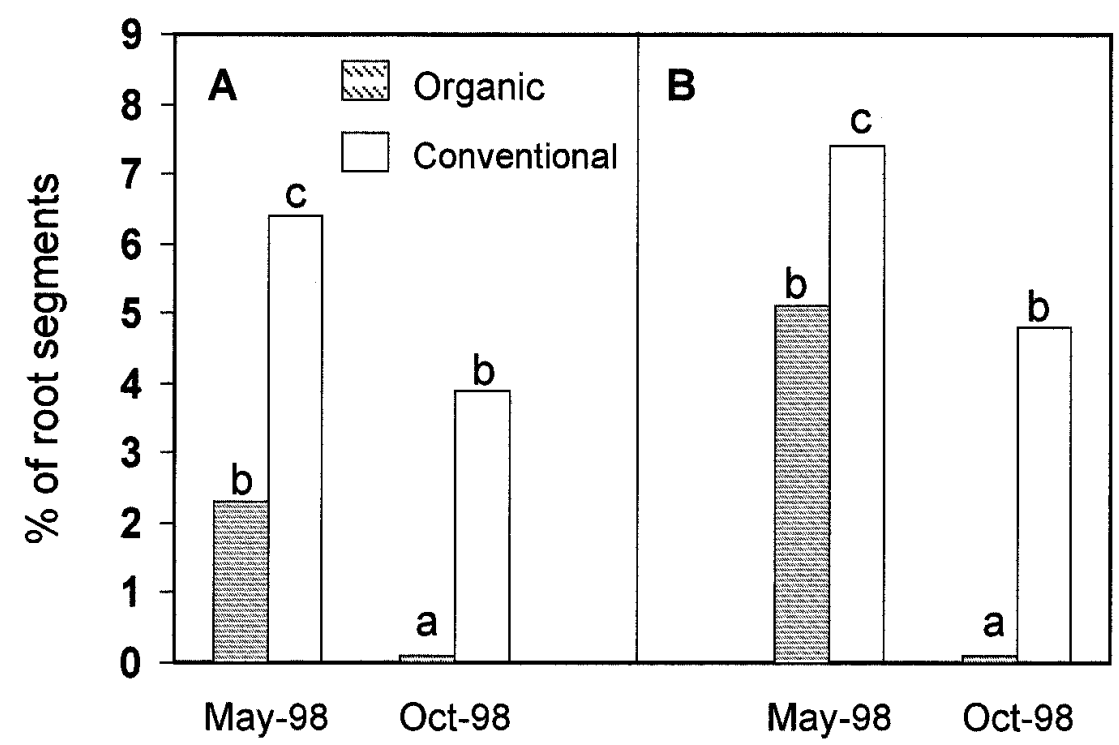

Fig. 1. Relative recovery (\%) of Pythium spp. from roots of apple grown using conventional and organic practices at A, the DO orchard, Zillah, WA and B, the DTF orchard Orondo, WA in 1998. For a given orchard, values followed by the same letters are not significantly different according to the Student-Newman-Keuls method $(\alpha=0.05)$. bran-corn meal $(0.5 \% \mathrm{wt} / \mathrm{wt})$ infested with individual nonpathogenic isolates. After 2 weeks, seedlings were transferred to sterile potting mix amended with oat bran-corn meal $(0.2 \% \mathrm{wt} / \mathrm{wt})$ infested with either $P$. sylvaticum or $P$. ultimum. Seedlings were grown for an additional 6 weeks in controlled environment chambers at $24^{\circ} \mathrm{C}$ with an 18-h day and 6-h night regime, after which root weight, shoot weight, and shoot length were determined. Ten root segments from each seedling were plated on PSSM to assess root infection by the respective species of Pythium. Controls included seedlings raised in sterile soil and planted into pathogen-infested soil, seedlings grown in soil infested with a nonpathogenic isolate of Pythium sp. and planted into sterile soil, and seedlings grown in sterile growth medium for the duration of the study.

Assessment of metalaxyl sensitivity. Corn meal agar (Difco Laboratories) was amended with metalaxyl (Ridomil 2E; Novartis Crop Protection, Greensboro, $\mathrm{NC})$ at a concentration of $0,0.05,0.1,0.5$, $1.0,2.5$, or $5.0 \mu \mathrm{g}$ a.i. $\mathrm{ml}^{-1}$. A 5-mm-diameter plug from the margin of a 3- or 4day-old Pythium sp. culture grown on PDA was transferred to the edge of each plate, with three replicate plates per fungicide concentration. Plates were incubated in the dark at $20^{\circ} \mathrm{C}$ and linear growth was assessed at 48 and $72 \mathrm{~h}$ after inoculation. Percent inhibition of radial growth was determined with respect to growth on nonamended media. Data were analyzed by linear regression and metalaxyl concentrations resulting in 50\% growth inhibition $\left(\mathrm{EC}_{50}\right)$ were estimated for each isolate from the resulting linear equations. Logittransformed percent inhibition data and $\log _{10}$-transformed fungicide concentration data were used in the analysis.

Statistical analyses. Data for plant growth and percent root infection were subjected to analysis of variance and means separation using the Student-Newman-Keuls method. Percent root infection data were transformed to arcsine-square root values prior to analysis. Statistical analyses were conducted using Sigma-Stat (ver. 2.0; SPSS, San Rafael, CA).

\section{RESULTS}

Species of Pythium recovered from apple roots. The composition of Pythium spp. populations varied significantly among orchards, and numerous species were recovered from apple (Table 1). In all, 17 different species of Pythium were recovered from apple roots among the six orchards surveyed. These included $P$. aphanidermatum, $P$. debaryanum (based on sequence similarity with CBS 752.96), $P$. dissotocum, $P$. flevoense, $P$. heterothallicum, $P$. intermedium, $P$. irregulare, $P$. iwayamae, $P$. macrosporum, $P$. sylvaticum, $P$. torulosum, and P. ultimum. In addition, putative new species having significant 
sequence differences with their closest match among the (neo-)type strains, namely Pythium MM1 (aff. macrosporum), Pythium MM2 (aff. iwayamae) Pythium MM3 (aff. oedochilum), Pythium MM4 (aff. rostratum), and Pythium MM5 (aff. vexans), were recovered from apple roots.
Dominant species included $P$. heterothallicum, $P$. intermedium, $P$. irregulare, and $P$. sylvaticum at the $\mathrm{CV}, \mathrm{DO}, \mathrm{DTF}$, and $\mathrm{WVC}$ orchards, respectively. No dominant species was evident in the population recovered from roots of apple at the GC orchard. Although seasonal differences were ob-

Table 2. Root infection and development of 'Gala' apple seedlings after 8 weeks of growth in pasteurized soil infested with Pythium sp. at a population of $4 \times 10^{2} \mathrm{CFU} \mathrm{g}{ }^{-1}$ soil

\begin{tabular}{|c|c|c|c|c|}
\hline Isolate & Orchard $^{x}$ & Infection $(\%)^{y}$ & Plant height (cm) & Plant weight (g) \\
\hline Control & & & 12.5 & 1.42 \\
\hline P. aphanidermatum 575 & $\mathrm{CV}$ & 20 bcde & 13.3 & 1.38 \\
\hline P. debarvanum 639 & DTF & $38 \mathrm{efgh}$ & 12.9 & 1.07 \\
\hline P. heterothallicum 550 & $\mathrm{CV}$ & $5 \mathrm{ab}$ & 9.5 & 1.03 \\
\hline P. heterothallicum 568 & DO & $10 a b c$ & 10.3 & 1.10 \\
\hline P. heterothallicum 572 & DO & $13 a b c$ & 9.9 & 1.11 \\
\hline P. intermedium 565 & DO & $28 \mathrm{cdef}$ & 10.4 & 1.06 \\
\hline P. intermedium 596 & $\mathrm{CV}$ & $1 \mathrm{a}$ & 14.0 & 1.65 \\
\hline P. irregulare 624 & DTF & $57 \mathrm{hi}$ & 10.5 & 1.02 \\
\hline Pythium MM2 593 & GC & 21 bcde & 10.0 & 0.94 \\
\hline P. macrosporum 563 & DO & $52 \mathrm{ghi}$ & 11.1 & 0.99 \\
\hline Pythium MM1 584 & GC & 37 defg & 14.3 & 1.45 \\
\hline Pythium MM1 600 & DO & $50 \mathrm{ghi}$ & 14.5 & 1.81 \\
\hline Pythium MM4 585 & $\mathrm{GC}$ & $13 \mathrm{abc}$ & 10.1 & 1.19 \\
\hline P. sylvaticum 540 & WVC & $63 \mathrm{i}$ & 10.4 & 1.14 \\
\hline P. sylvaticum 566 & DO & $17 \mathrm{abcd}$ & 11.4 & 1.25 \\
\hline P. sylvaticum 632 & WVC & $25 \mathrm{cdef}$ & 14.2 & 1.53 \\
\hline P. sylvaticum 642 & DTF & $55 \mathrm{hi}$ & 10.2 & 1.03 \\
\hline P. ultimum 662 & DR & 34 defg & 10.7 & 0.97 \\
\hline P. ultimum 664 & DR & $26 \mathrm{cdef}$ & 10.1 & 1.04 \\
\hline Pythium MM5 1-19 & DR & $10 \mathrm{ab}$ & 12.0 & 1.48 \\
\hline Pythium MM5 589 & WVC & 45 fghi & 12.1 & 1.57 \\
\hline $\operatorname{LSD}(P=0.05)^{\mathrm{z}}$ & $\ldots$ & $\ldots$ & 1.3 & 0.17 \\
\hline
\end{tabular}

${ }^{\mathrm{x}}$ CV orchard, Orondo; DO orchard, Zillah; DR orchard, Moxee; DTF orchard, Orondo; GC orchard, Manson; WVC orchard, Wenatchee, WA.

${ }^{y}$ Values in a column followed by the same letter are not significantly different according to the Student-Newman-Keuls method $(\alpha=0.05)$.

${ }^{\mathrm{z}} \mathrm{LSD}=$ least significant difference.

Table 3. Root infection and growth of 'Gala' apple seedlings after 12 weeks of growth in pasteurized soil amended with corn meal-oat bran infested with an isolate of Pythium sp. at a rate of $0.2 \%$ (wt/wt)

\begin{tabular}{|c|c|c|c|c|}
\hline Isolate & $\operatorname{Orchard}^{x}$ & Infection $(\%)^{\mathrm{y}}$ & Plant height (cm) & Plant weight (g) \\
\hline Control & & & 14.3 & 4.29 \\
\hline P. aphanidermatum 575 & $\mathrm{CV}$ & $21 \mathrm{bc}$ & 13.6 & 3.87 \\
\hline P. debaryanum 639 & DTF & $9 \mathrm{a}$ & 9.9 & 2.39 \\
\hline P. heterothallicum 550 & $\mathrm{CV}$ & $68 \mathrm{~g}$ & 11.0 & 3.37 \\
\hline P. heterothallicum 568 & DO & $17 \mathrm{ab}$ & 9.6 & 2.08 \\
\hline P. heterothallicum 572 & DO & $69 \mathrm{~g}$ & 11.3 & 3.23 \\
\hline P. intermedium 565 & DO & $32 \mathrm{~cd}$ & 10.2 & 2.27 \\
\hline P. intermedium 596 & $\mathrm{CV}$ & $53 \mathrm{f}$ & 15.4 & 4.11 \\
\hline P. irregulare 624 & DTF & 39 de & 8.0 & 2.39 \\
\hline Pythium MM2 593 & GC & $6 \mathrm{a}$ & 15.0 & 3.81 \\
\hline P. macrosporum 563 & DO & $27 \mathrm{bcd}$ & 12.4 & 2.89 \\
\hline Pythium MM1 584 & GC & $24 \mathrm{bc}$ & 14.1 & 3.84 \\
\hline Pythium MM1 600 & DO & $33 \mathrm{~cd}$ & 13.5 & 3.90 \\
\hline Pythium MM4 585 & $\mathrm{GC}$ & $31 \mathrm{~cd}$ & 14.5 & 3.56 \\
\hline P. sylvaticum 540 & WVC & $90 \mathrm{~h}$ & 10.4 & 3.12 \\
\hline P. sylvaticum 566 & DO & $68 \mathrm{~g}$ & 10.7 & 2.92 \\
\hline P. sylvaticum 632 & WVC & $5 \mathrm{a}$ & 14.0 & 4.08 \\
\hline P. sylvaticum 642 & DTF & $91 \mathrm{~h}$ & 9.8 & 2.43 \\
\hline P. ultimum 662 & DR & $54 \mathrm{f}$ & 7.7 & 1.83 \\
\hline P. ultimum 664 & DR & 50 ef & 8.1 & 1.95 \\
\hline Pythium MM5 1-19 & $\mathrm{DR}$ & $13 \mathrm{ab}$ & 14.3 & 5.50 \\
\hline Pythium MM5 589 & WVC & $81 \mathrm{gh}$ & 14.7 & 4.96 \\
\hline $\operatorname{LSD}(P=0.05)^{\mathrm{z}}$ & $\ldots$ & $\ldots$ & 2.2 & 0.78 \\
\hline
\end{tabular}

${ }^{x}$ CV orchard, Orondo; DO orchard, Zillah; DR orchard, Moxee; DTF orchard, Orondo; GC orchard, Manson; WVC orchard, Wenatchee, WA.

${ }^{y}$ Values in a column followed by the same letter are not significantly different according to the Student-Newman-Keuls method $(\alpha=0.05)$.

${ }^{\mathrm{z}} \mathrm{LSD}=$ least significant difference. served in relative isolation frequency, the species composition of Pythium populations recovered from apple roots was similar in the May and October samples.

Populations of Pythium spp. recovered from orchard soils ranged from $67 \mathrm{CFU} \mathrm{g}^{-1}$ at the $\mathrm{GC}$ orchard to $506 \mathrm{CFU} \mathrm{g}^{-1}$ at the DO orchard. Relative recovery of Pythium spp. from roots of apple varied with orchard site, collection date, and management system. The lowest infection rate was recorded for trees from the GC orchard where Pythium spp. were consistently recovered from less than $1 \%$ of root segments. Root infection from the remaining orchard sites ranged from $<1.0$ to $19.3 \%$, depending upon collection date and management system. In general, percent recovery was higher from root systems collected in the spring than in the fall (Fig. 1). An exception to this trend was the CV orchard, where relative recovery of Pythium spp. from apple roots was similar in the spring and fall samples collected in 1998. During 1998, root infection by Pythium spp. was higher for trees grown under conventional management practices than those grown in organic systems at both the DO and DTF orchards (Fig. 1). Similar results were obtained at the DO orchard in May 1999. Pythium spp. root infection was significantly higher $(P=0.018)$ for trees from the conventional blocks $(19.3 \%)$ than the organic blocks (7.4\%).

Associations between apple and species of Pythium. Twenty-one selected isolates of Pythium spp. were evaluated in assays on Gala seedlings. The effects of Pythium spp. on growth of apple (Tables 2 and 3) varied, and ranged from promotion to significant suppression of plant growth. Isolates of $P$. heterothallicum, $P$. intermedium, $P$. irregulare, and P. ultimum consistently caused stunting of apple seedlings and decreased plant biomass. Three of four isolates of $P$. sylvaticum caused stunting of apple, whereas $P$. sylvaticum isolate 632 appeared to be avirulent. Among all species and orchard sources, isolates of $P$. ultimum from the DR orchard caused the greatest stunting and reductions in biomass of Gala seedlings (Tables 2 and 3). In contrast, several species of Pythium recovered from apple roots had no impact on growth of apple seedlings (Tables 2 and 3). The growth response of apple seedlings induced by individual isolates of Pythium spp. was typically similar whether fungal inoculum was in the form of precolonized soil or colonized corn meal-oat bran. A notable exception was evident for Pythium MM2 isolate 593, which colonized the corn meal-oat bran very slowly and failed to significantly colonize apple roots or impact seedling growth when introduced on this substrate.

Relative infection of apple roots by different isolates and species of Pythium varied, but infection frequency did not necessarily correlate with the level of damage to 
apple. When soil inoculum was utilized (Table 2), percent root infection by virulent isolates of $P$. sylvaticum was generally high, whereas the rate of root infection among isolates of $P$. heterothallicum was lower. Certain isolates of Pythium MM1 and Pythium MM5 aggressively colonized the roots of apple and enhanced or did not limit seedling growth.

Use of nonpathogenic Pythium spp. as biocontrol agents. When planted into noninfested soil, isolate 584 of Pythium MM1 and isolate 1-12 of Pythium MM3, but not Pythium MM5 isolate 1-19, enhanced growth of apple seedlings (Table 4). Precolonization of apple roots with any of the three Pythium spp. isolates significantly reduced root infection by $P$. ultimum 664 (Table 5), resulting in enhanced growth of apple seedlings (Table 4). Nonpathogenic Pythium spp. also suppressed root infection by $P$. sylvaticum 566, resulting in an increase in seedling shoot length and biomass (Table 4). In the initial experiment, isolate 584 or 1-12 also enhanced root biomass of Gala seedlings planted in $P$. sylvaticum-infested soils, but only isolate 1-12 provided the same response in the second experiment. Pythium MM5 isolate 1-19 was less effective than isolate 584 or 1-12 in suppressing root infection (Table 5), and did not improve growth of Gala seedlings in soil infested with $P$. ultimum 664 in the second experiment.

Sensitivity to metalaxyl. Isolates of $P y$ thium recovered from apple roots at the six orchards surveyed in 1998 exhibited a wide range in sensitivities to metalaxyl (Table 6). $\mathrm{EC}_{50}$ values typically ranged from 0.01 to $5.0 \mu \mathrm{g} \mathrm{ml}^{-1}$. One notable exception was Pythium MM3 isolate 1-12 from the DR orchard, which possessed an $\mathrm{EC}_{50}$ value $>5.0 \mu \mathrm{g} \mathrm{ml}^{-1}$. Isolates of $P$. heterothallicum were recovered from three orchards and were uniformly sensitive to this fungicide (EC Ev $_{50}$ values: 0.01 to $0.21 \mu \mathrm{g} \mathrm{ml}{ }^{-1}$ ), whereas isolates of Pythium MM3 and Pythium MM5 were relatively insensitive. Isolates of $P$. sylvaticum varied in sensitiv- ity to metalaxyl but did so in an orchardspecific manner. Isolates from the DO

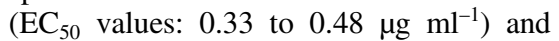
WVC ( $\mathrm{EC}_{50}$ values: 0.17 to $0.56 \mu \mathrm{g} \mathrm{ml}^{-1}$ ) orchards were sensitive to metalaxyl, whereas P. sylvaticum isolates from the GC orchard were relatively insensitive $\left(\mathrm{EC}_{50}\right.$ values: 0.9 to $1.35 \mu \mathrm{g} \mathrm{ml}^{-1}$ ).

\section{DISCUSSION}

Previous studies have implicated a number of Pythium spp. as potential pathogens of apple across a broad area of the world, but reported diversity of the population within a given region has been limited. For instance, Utkhede and Smith (31) suggested that $P$. ultimum was the significant species affecting apple in British Columbia, whereas $P$. sylvaticum dominated the population recovered from apple roots and orchard soils in the United Kingdom (28). In the current study, conducted in a limited geographic region, we observed great diversity in the species composition of $P y$ thium spp. populations associated with apple at a given site. The greater diversity observed in the current study could be real but also could be explained by the intensive sampling conducted and the improved accuracy in identification of Pythium spp. by DNA sequencing of ribosomal DNA. However, although the primary species recovered from apple roots varied among orchards, the population from any particular site was typically dominated by one species of Pythium that was pathogenic toward apple.

Orchard management practices appear to have a significant impact on relative activity of Pythium spp. as pathogens of apple. Although differences in species composition were not observed between management systems, recovery of Pythium spp. from apple roots was consistently higher from trees grown using conventional practices than from trees in adjacent organic blocks. Defining attributes of the management systems that contribute to these distinctions was not the subject of study; however, the variation in apple root infection may be a function of differences in relative microbial activity, soil fertility, and plant diversity, among other factors. The potential benefit of the organic system to overall root health also is not evident because root infection by Rhizoctonia spp., which also are pathogens of apple (17), was significantly higher in organic than the corresponding conventional blocks (M. Mazzola, unpublished data). This finding was anticipated because previous studies have documented the antagonistic relationships between Pythium spp. and Rhizoctonia spp. (26,33), and enhanced apple root infection by members of one genus when populations of the other are chemically suppressed (18).

Our studies demonstrated that a number of Pythium spp. have potential to function as significant pathogens of apple. How-

Table 5. Impact of precolonization with nonpathogenic Pythium spp. on infection of 'Gala' seedling roots by Pythium ultimum strain 664 or P. sylvaticum strain $566^{z}$

\begin{tabular}{lccccc}
\hline & \multicolumn{4}{c}{ Root infection (\%) } \\
\cline { 2 - 3 } \cline { 2 - 3 } \cline { 5 - 6 } Treatment & \multicolumn{2}{c}{ P. sylvaticum 566 } & & \multicolumn{2}{c}{ P. ultimum 664 } \\
\hline Control & $96 \mathrm{c}$ & $\mathbf{E x p ~ 2}$ & & Exp 1 & Exp 2 \\
Pythium MM1 584 & $13 \mathrm{ab}$ & $9 \mathrm{a}$ & & $39 \mathrm{~b}$ & $48 \mathrm{c}$ \\
Pythium MM3 1-12 & $19 \mathrm{~b}$ & $18 \mathrm{a}$ & & $8 \mathrm{a}$ & $3 \mathrm{a}$ \\
Pythium MM5 1-19 & $5 \mathrm{a}$ & $16 \mathrm{a}$ & & $16 \mathrm{a}$ & $4 \mathrm{a}$ \\
\hline
\end{tabular}

${ }^{\mathrm{z}}$ Exp $=$ experiments 1 and 2 . Values in a column followed by the same letter are not significantly different according to the Student-Newman-Keuls method $(\alpha=0.05)$.

Table 4. Impact of precolonization of apple roots with nonpathogenic Pythium spp. on growth of 'Gala' seedlings in noninfested soil and soil infested with Pythium ultimum strain 664 or P. sylvaticum strain $566^{\mathrm{y}}$

\begin{tabular}{|c|c|c|c|c|c|c|}
\hline \multirow[b]{2}{*}{ Treatment } & \multicolumn{2}{|c|}{ Root weight (g) } & \multicolumn{2}{|c|}{ Shoot weight (g) } & \multicolumn{2}{|c|}{ Shoot height $(\mathrm{cm})$} \\
\hline & $\operatorname{Exp} 1$ & $\operatorname{Exp} 2$ & $\operatorname{Exp} 1$ & $\operatorname{Exp} 2$ & $\operatorname{Exp} 1$ & $\operatorname{Exp} 2$ \\
\hline Control & 0.84 & 0.63 & 2.68 & 2.41 & 17.1 & 16.4 \\
\hline Pythium MM1 584 & 1.35 & 1.73 & 4.32 & 4.83 & 23.6 & 23.4 \\
\hline Pythium MM3 1-12 & 1.30 & 0.99 & 4.00 & 3.32 & 21.7 & 21.1 \\
\hline Pythium MM5 1-19 & 0.72 & 0.92 & 3.18 & 2.57 & 18.7 & 20.8 \\
\hline P. sylvaticum 566 & 0.48 & 0.36 & 1.69 & 1.55 & 13.3 & 14.3 \\
\hline P. ultimum 664 & 0.53 & 0.57 & 1.70 & 1.68 & 12.6 & 13.7 \\
\hline P. sylvaticum $566+$ Pythium MM1 584 & 1.10 & 0.72 & 4.05 & 3.97 & 21.8 & 21.2 \\
\hline P. sylvaticum 566+ Pythium MM3 1-12 & 1.05 & 1.09 & 3.78 & 3.86 & 19.0 & 18.4 \\
\hline P. sylvaticum 566+ Pythium MM5 1-19 & 0.67 & 0.81 & 3.76 & 4.04 & 20.4 & 21.3 \\
\hline P. ultimum 664 + Pythium MM1 584 & 0.97 & 1.43 & 2.72 & 4.40 & 18.6 & 21.8 \\
\hline P. ultimum 664 + Pythium MM3 1-12 & 1.22 & 1.46 & 2.65 & 3.76 & 20.6 & 20.2 \\
\hline P. ultimum 664 + Pythium MM5 1-19 & 1.02 & 0.73 & 2.56 & 2.45 & 16.2 & 17.1 \\
\hline $\operatorname{LSD}(P=0.05)^{\mathrm{z}}$ & 0.27 & 0.61 & 0.62 & 1.07 & 2.8 & 3.7 \\
\hline
\end{tabular}

y Exp $=$ experiments 1 and 2.

${ }^{\mathrm{z}} \mathrm{LSD}=$ least significant difference. 
ever, among virulent isolates from any given site, a particular Pythium sp. appears to occupy the role of pathogen while the group of nonpathogenic species is more diverse, and the latter generally are present in limited numbers based on recovery from apple roots. The role of these organisms in limiting growth and productivity of longestablished trees at these sites is not clear. Based upon previous studies (18) and the populations of Pythium spp. recovered from the orchards surveyed, it is likely that Pythium spp. will pose a significant obstacle to the growth of newly established trees should these sites be renovated.

Although many Pythium spp. were virulent toward apple, based on recovery from apple roots and characteristics exhibited in plant bioassays, only a limited number of species are likely to play a significant role in limiting productivity of apple in Washington. $P$. heterothallicum, $P$. intermedium, and $P$. sylvaticum dominated the population recovered from roots of apple in one or more of the orchards surveyed and were pathogenic toward apple in bioassays. Interestingly, $P$. heterothallicum caused significant damage to apple even though, in bioassays, it was one of the least aggressive colonizers of apple roots when introduced at a population of $4 \times 10^{2} \mathrm{CFU} \mathrm{g}^{-1}$ (Table 2). P. ultimum was recovered infrequently from the roots of field-grown apple. However, based on plant assays, it is likely to be a significant pathogen of apple because isolates of this species consistently caused the greatest stunting of Gala seedlings.

Certain Pythium spp. recovered from apple roots were able to colonize Gala seedling roots but had no impact on seedling growth. Isolates belonging to the Pythium MM1, Pythium MM3, and Pythium MM5 groups often enhanced growth of apple in pasteurized soil. Dewan and Sivasithamparam (6) reported a similar finding; growth of wheat and ryegrass plants was enhanced by $P$. vexans in sterilized and nonsterilized soils. When allowed to pre- colonize seedling roots, certain isolates of the nonpathogenic Pythium spp. (MM1, MM3, and MM5) were able to limit infection of apple seedling roots by $P$. sylvaticum and $P$. ultimum, resulting in enhanced growth of seedlings in artificially infested soils. Mycoparasitic species of the genus Pythium, including $P$. oligandrum and $P$. nunn, have shown potential as agents for the biological control of pathogenic $P y$ thium spp. $(14,16,22,23)$. Recently, it was demonstrated that $P$. oligandrum can act as a mycoparasite (25) and produces the proteinaceous molecule oligandrin which can induce plant defense responses (24). None of the Pythium spp. that demonstrated biological control in this study have demonstrated obvious mycoparasitism. It is possible that all three isolates limited root infection by $P$. sylvaticum and $P$. ultimum through competition for infection sites or substrate because the nonpathogenic isolates were allowed to colonize the apple root system prior to planting seedlings in pathogen infested soil.

The species-specific nature of sensitivity to the fungicide metalaxyl among Pythium spp. observed in this study is in agreement with previous reports. Isolates of $P$. aphanidermatum from sugar beet were less sensitive to metalaxyl than isolates of $P$. ultimum var. sporangiiferum from the same host (2). Likewise, sensitivity to metalaxyl among isolates of Pythium spp. recovered from wheat in the Pacific northwest was observed to be species dependent; $P$. irregulare and $P$. torulosum were insensitive, whereas $P$. aristosporum, $P$. heterothallicum, and $P$. ultimum were sensitive to this fungicide (5). Pythium spp. commonly recovered in our study exhibited rather uniform sensitivity to metalaxyl across sites of origin. Isolates of $P$. heterothallicum were highly sensitive and isolates of Pythium MM1 were moderately sensitive to metalaxyl, regardless of the source orchard. The notable exception to this pattern was observed among isolates of $P$. sylvaticum. Although recovery from apple roots was consistently low, isolates obtained from the GC orchard were less sensitive to metalaxyl ( $\mathrm{EC}_{50}$ values: 0.90 to $1.35 \mu \mathrm{g} \mathrm{ml}^{-1}$ ) than isolates from any other site $\left(\mathrm{EC}_{50}\right.$ values: 0.12 to $\left.0.56 \mu \mathrm{g} \mathrm{ml}^{-1}\right)$. It is interesting to note that the GC orchard is the only site examined in this study with a history of metalaxyl use, which suggests that repeated fungicide application may account for this observation.

Interestingly, the three disease-suppressive isolates of Pythium spp. used in these studies exhibited some of the highest levels of metalaxyl resistance among all isolates examined. The level of insensitivity detected among some of these nonpathogenic Pythium spp. may provide an opportunity to reduce fungicide rates through the application of an integrated pest management strategy. It is possible that effective control of pathogenic Pythium spp. using reduced rates of metalaxyl may be achieved when applied in conjunction with highly insensitive nonpathogenic Pythium spp., such as Pythium MM3 isolate 1-12. Such a strategy, of course, would first require confirmation that the insensitive nature of these isolates observed in vitro translates to a similar response in natural soil systems.

\section{LITERATURE CITED}

1. Bakkeren, G., Kronstad, J. W., and Lévesque, C. A. 2000. Comparison of AFLP fingerprints and ITS sequences as phylogenetic markers in Ustilaginomycetes. Mycologia 92:510-521.

2. Brantner, J. R., and Windels, C. E. 1998. Variability in sensitivity to metalaxyl in vitro, pathogenicity and control of Pythium spp. on sugar beet. Plant Dis. 82:896-899.

3. Braun, P. G. 1995. Effects of Cylindrocarpon and Pythium species on apple seedlings and potential role in apple replant disease. Can. J. Plant Pathol. 17:336-341.

4. Cook, R. J., and Baker, K. F. 1983. The Nature and Practice of Biological Control of Plant Pathogens. The American Phytopathological Society, St. Paul, MN.

5. Cook, R. J., and Zhang, B.-X. 1985. Degrees of sensitivity to metalaxyl within the Pythium spp. pathogenic to wheat in the Pacific Northwest. Plant Dis. 69:686-688.

6. Dewan, M. M., and Sivasithamparam, K. 1988. Pythium spp. in roots of wheat and rye-

Table 6. Metalaxyl sensitivity of isolates of Pythium recovered from roots of apple at the respective orchards in 1998

\begin{tabular}{|c|c|c|c|c|c|c|}
\hline \multirow[b]{2}{*}{ Species } & \multicolumn{6}{|c|}{ Metalaxyl concentrations resulting in $50 \%$ growth inhibition $\left(\mu \mathrm{g} \mathrm{ml}^{-1}\right)$ per orchard } \\
\hline & CV & DO & $\mathbf{D R}^{\mathbf{z}}$ & DTF & GC & WVC \\
\hline P. debaryanum & $\ldots$ & & $\ldots$ & $0.22-0.76$ & $\ldots$ & \\
\hline P. dissotocum & $\ldots$ & 0.80 & $\ldots$ & $\ldots$ & $\ldots$ & $0.60-0.75$ \\
\hline P. heterothallicum & $<0.01-0.18$ & $0.17-0.19$ & $\ldots$ & $0.19-0.21$ & 0.18 & $\ldots$ \\
\hline P. intermedium & $<0.01-0.21$ & $0.26-0.67$ & $\ldots$ & $\ldots$ & $\ldots$ & 0.20 \\
\hline$P$. irregulare & $\ldots$ & $\ldots$ & $\ldots$ & $0.20-0.79$ & $\ldots$ & $\ldots$ \\
\hline Pythium MM2 & $<0.01$ & $\ldots$ & $\ldots$ & $\ldots$ & $0.28-0.46$ & $\ldots$ \\
\hline P. macrosporum & $\ldots$ & 2.76 & $\ldots$ & $\ldots$ & $\ldots$ & $\ldots$ \\
\hline Pythium MM1 & 0.48 & $0.63-0.79$ & $\ldots$ & $\ldots$ & $0.56-1.47$ & $\ldots$ \\
\hline Pythium MM3 & $\ldots$ & $\ldots$ & $>5.0$ & $\ldots$ & $\ldots$ & $\ldots$ \\
\hline Pythium MM4 & $\ldots$ & $\ldots$ & $\ldots$ & $\ldots$ & 0.13 & 0.11 \\
\hline P. sylvaticum & $\ldots$ & $0.33-0.48$ & $\ldots$ & $\ldots$ & $0.90-1.35$ & $0.12-0.56$ \\
\hline P. torulosum & $\ldots$ & 0.69 & $\ldots$ & $\ldots$ & $\ldots$ & $\ldots$ \\
\hline P. ultimum & $\ldots$ & $\ldots$ & $0.01-0.02$ & $\ldots$ & $\ldots$ & 0.17 \\
\hline Pythium MM5 & $\ldots$ & $\ldots$ & 1.38 & $\ldots$ & $\ldots$ & $0.64->5.0$ \\
\hline
\end{tabular}

y CV orchard, Orondo; DO orchard, Zillah; DR orchard, Moxee; DTF orchard, Orondo; GC orchard, Manson; WVC orchard, Wenatchee, WA.

${ }^{\mathrm{z}}$ Isolates from the DR orchard were obtained in a previous study (18). 
grass in western Australia and their effect on root rot caused by Gaeumannomyces graminis var. tritici. Soil Biol. Biochem. 20:801-808.

7. Dick, M. W. 1990. Key to Pythium. University of Reading Press, Reading, UK.

8. Dullahide, S. R., Stirling, G. R., Nikulin, A., and Stirling, A. M. 1994. The role of nematodes, fungi, bacteria, and abiotic factors in the etiology of apple replant problems in the Granite Belt of Queensland. Aust. J. Exp. Agric. 34:1177-1182.

9. Hassan, N. M. M. B. H. N. 1987. Distribution and survival of Phytophthora cactorum in irrigated orchard soil in Washington. Ph.D. dissertation, Washington State University, Pullman.

10. Jeffers, S. N., and Aldwinckle, H. S. 1988. Phytophthora crown rot of apple trees: Sources of Phytophthora cactorum and $P$. cambivora as primary inoculum. Phytopathology 78:328-335.

11. Jeffers, S. N., Aldwinckle, H. S., Burr, T. J., and Arneson, P. A. 1982. Phytophthora and Pythium species associated with crown rot in New York apple orchards. Phytopathology 72:533-538.

12. Jones, A. L., and Aldwinckle, H. S. 1990. Compendium of Apple and Pear Diseases. American Phytopathological Society, St. Paul, $\mathrm{MN}$.

13. Knudsen, I. M. B., Debosz, K., Hockenhull, J., Jensen, D. F., and Elmholt, S. 1999. Suppressiveness of organically and conventionally managed soils towards brown foot rot of barley. Appl. Soil. Ecol. 12:61-72.

14. Lifshitz, R., Sneh, B., and Baker, R. 1984. Soil suppressiveness to Pythium ultimum induced by antagonistic Pythium spp. Phytopathology 74:1054-1061.

15. Martin, F. N. 1992. Pythium. Pages 39-49 in: Methods for Research on Soilborne Phytopa- thogenic Fungi. L. L. Singleton, J. D. Mihail, and C. M. Rush, eds. American Phytopathological Society, St. Paul, MN.

16. Martin, F. N., and Hancock, J. G. 1987. The use of Pythium oligandrum for biological control of pre-emergence damping-off caused by $P$. ultimum. Phytopathology 77:1013-1020.

17. Mazzola, M. 1997. Identification and pathogenicity of Rhizoctonia spp. isolated from apple roots and orchard soils. Phytopathology 87:582-587.

18. Mazzola, M. 1998. Elucidation of the microbial complex having a causal role in the development of apple replant disease in Washington. Phytopathology 88:930-938.

19. Mazzola, M., Granatstein, D. M., Elfving, D. C., and Mullinix, K. M. 2001. Suppression of specific apple root pathogens by Brassica napus seedmeal amendment regardless of glucosinolate content. Phytopathology 91:673679.

20. McIntosh, D. L. 1966. The occurrence of Phytophthora spp. in irrigation water in British Columbia. Can. J. Bot. 44:1591-1596.

21. Mulder, D. 1969. The pathogenicity of several Pythium species to rootlets of apple seedlings. Neth. J. Plant Pathol. 75:178-181.

22. Paulitz, T. C., and Baker, R. 1987. Biological control of Pythium damping-off of cucumbers with Pythium nunn: Population dynamics and disease suppression. Phytopathology 77:335340.

23. Paulitz, T. C., and Baker, R. 1987. Biological control of Pythium damping-off of cucumbers with Pythium nunn: Influence of soil environment and organic amendments. Phytopathology 77:341-346.

24. Picard, K., Ponchet, M., Blein, J. P., Rey, P., Tirilly, Y., and Benhamou, N. 2000. Oligandrin. A proteinaceous molecule produced by the mycoparasite Pythium oligandrum induces resistance to Phytophthora parasitica infection in tomato plants. Plant Physiol. 124:379-395.

25. Picard, K., Tirilly, Y., and Benhamou, N. 2000. Cytological effects of cellulases in the parasitism of Phytophthora parasitica by $P y$ thium oligandrum. Appl. Environ. Microbiol. 66:4305-4314

26. Pieczarka, D. J., and Abawi, G. S. 1978. Effects of interaction between Fusarium, Pythium, and Rhizoctonia on severity of bean root rot. Phytopathology 68:403-408.

27. Reganold, J. P., Glover, J. D., Andrews, P. K. and Hinman, H. R. 2001. Sustainability of three apple production systems. Nature 410:926-930

28. Sewell, G. W. F. 1981. Effects of Pythium species on the growth of apple and their possible causal role in apple replant disease. Ann. Appl. Biol. 97:31-42.

29. Tidball, C. J., and Linderman, R. G. 1990. Phytophthora root and stem rot of apple from stool beds. Plant Dis. 74:141-146.

30. Utkhede, R. S., and Gupta, V. K. 1988. In vitro selection of strains of Phytophthora cactorum resistant to metalaxyl. J. Phytopathol. 122:35-44.

31. Utkhede, R. S., and Smith, E. M. 1991. Phytophthora and Pythium species associated with root rot of young apple trees and their control. Soil Biol. Biochem. 23:1059-1063.

32. Van der Plaats-Niterink, A. J. 1981. Monograph of the genus Pythium. Stud. Mycol. $21: 1-242$

33. Xi, K., Stephens, J. H. G., and Hwang, S. F. 1995. Dynamics of pea seed infection by $P y$ thium ultimum and Rhizoctonia solani: Effects of inoculum density and temperature on seed rot and pre-emergence damping-off. Can. J Plant Pathol. 17:19-24. 